УДК $616.1 / .9$

https://doi.org/10.52692/1857-0011.2021.3-71.15

\title{
LIPID SPECTRUM IN PATIENTS WITH PULMONARY TUBERCULOSIS
}

\author{
Dmitriy Sergeevich RYASENSKIY, Candidate of Medical Sciences, Associate Professor. \\ Alexander Vladimirovich ASEEV, Doctor of Medical Sciences, Head of the Department \\ Akhmed Ibragimovich ELGALI, Assistant at the Department \\ Tver State Medical University of the Ministry of Health of the Russian Federation, \\ Department of Phthisiology, 170100, Tver, Russia
}

\begin{abstract}
.
The evaluation of the lipid spectrum of the blood plasma and immunocyte membranes is important for timely diagnostic and correction of pathological changes revealed at the cytochemical level. The identification of lipid fractions using high-performance liquid chromatography (HPLC) allows for separate detection of minor fractions of lysophospholipids (lysophosphatidylcholine and lysophosphatidylethanolamine). The study was performed using a photometric sensor and reverse-phase column C18. The following fractions were obtained: lysophosphatidylcholine, lysophosphatidylethanolamine, sphingomyelin, phosphatidylcholine, phosphatidylethanolamine, phosphatidylinositol, and phosphatidylserine. The ratio of these fractions is a sensitive marker of pathological shifts in the lipid spectrum both in the blood plasma and immunocyte membranes.
\end{abstract}

Keywords: Lipid spectrum of the blood plasma, immunocytes, pulmonary tuberculosis.

\section{Rezumat. Determinarea spectrului lipidic la pacienții cu tuberculoză pulmonară.}

Determinarea spectrului lipidic al plasmei sanguine și al membranelor plasmatice și imunocitelor este importantă pentru detectarea și corectarea în timp util a modificărilor patologice determinate la nivel citochimic. Determinarea fracțiilor lipidice prin cromatografie lichidă de înaltă performanță (HPLC) permite detectarea separată a fracțiilor minore de lizofosfolipide: lizofosfatidilcolină, lizofosfatidiletanolamină. Studiul a fost realizat folosind un senzor fotometric și o coloană cu fază inversă C18. S-au obţinut următoarele fracţii: lizofosfatidilcolină, lizofosfatidiletanolamină, sfingomielină, fosfatidilcolină, fosfatidiletanolamină, fosfatidilinozitol, fosfatidilserina. Raportul dintre aceste fracții este un marker sensibil al modificărilor patologice în spectrul lipidic, atât în plasma sanguină, cât și în membranele imunocitelor.

Cuvinte cheie: Spectrul lipidic al plasma sanguină, imunocite, tuberculoză pulmonară.

\section{Резюме. Определение липидного спектра у больных туберкулезом легких}

Определение липидного спектра плазмы крови и мембран иммуноцитов имеет важное значение для своевременного выявления и коррекции патологических изменений, определяемых на цитохимическом уровне. Определение липидных фракций с помощью высоко эффективной жидкостной хроматографии (ВЭЖХ), позволяет раздельно детектировать минорные фракции лизофосфолипидов: лизофосфатидилхолин, лизофосфатидилэтаноламин. Исследование проводилось с использованием фотометрического датчика и обратнофазной колонки С18. Были получены следующие фракции: лизофосфатидилхолин, лизофосфатидилэтаноламин, сфингомиелин, фосфатидилхолин, фосфатидилэтаноламин, фосфатидилинозитол, фосфатидилсерин. Соотношение данных фракций является чувствительным маркером патологических сдвигов липидного спектра, как в плазме крови, так и в мембранах иммуноцитов.

Ключевые слова: Липидный спектр плазмы крови, иммуноциты, туберкулез легких.

\section{Introduction}

Tuberculosis is one of the most acute problems in modern medicine. медицины. In Russia, tuberculosis has the highest economic burden per 1 case of the disease. The significance of this problem is associated with the wide spread of tuberculosis. In 1993, the WHO announced tuberculosis as a global issue. The priorities in the studies included molecular biology, social anthropology, and the economics of healthcare [5].

The study of the peculiarities of the lipid composition of the blood plasma and immunocompetent cell membranes in patients with tuberculosis of different localization is important for the development of the program of pathogenetic treatment of this disease.
The changes in the spectrum of cellular lipids are the most significant parameters of immune reactivity and direct indication of the functional condition of its separate elements. Lipids of blood cell membranes provide the molecular basis that determines their structural and functional properties [8]. The optimal functioning of the immune cells primarily depends on the biophysical properties of the cell membranes and is determined by the composition and ratio of different lipid fractions [6].

The evaluation of peculiarities of changes in the lipid spectrum of the plasma and cell membranes will allow the specialists to diagnose pathological conditions associated with lipid metabolism disorders as well as to perform their timely correction, which will 
increase the efficacy and the tolerability of antituberculosis therapy.

However, presently, the majority of publications are dedicated to the study of the lipid spectrum of the blood plasma. At the same time, the most important parameters of the ratio of lipid fractions of cell membranes and blood plasma lipids are not considered. To obtain a complete picture of changes in the lipid metabolism in patients with tuberculosis, it is necessary to expand the spectrum of the studied lipids, especially, its minor fractions.

Numerous methods of identification of the lipid spectrum of the blood and biological membranes were proposed. The main method of study is chromatography. Until now, the majority of researchers studied lipids using continuous-flow chromatography with further densitometry $[1,3]$. However, this method is very sensitive to external conditions, it is labor-consuming, and not highly efficient [4]. Presently, the method of high-performance liquid chromatography (HPLC) with further mass-spectrometry is becoming more widespread $[2,7]$. This method exerts good selectivity and provides results with high resolution. However, mass-spectrometry is not always available due to the high cost of equipment. It is possible to register lipid fractions in the required volume with a more available photometric sensor. The authors did not find any publications on the descriptions of the methods of evaluation of the lipid spectrum of plasma and cell membrane with HPLC and photometric sensor.

The study is aimed to propose a method of evaluation of the lipid spectrum and blood cell membranes in patients with tuberculosis using HPLC and photometric sensors.

\section{Materials and Methods}

The object of the study was the blood obtained from patients with tuberculosis that were receiving therapy at the regional clinical antituberculosis center. The blood was sampled from a vein. Further, the isolation of cellular elements was performed. The most widespread method for the isolation of separate fractions of cellular elements of the whole blood is the separation of whole blood on the gradient of density (ficoll-verographin) with further washing out of the admixtures of erythrocytes with a $0.84 \%$ solution of ammonium chloride. The extraction was performed by the method of Folch and Bligh-Dyer. HPLC separation was performed using a reverse-phase column $\mathrm{C} 18$. The eluent included a mixture of water, triethylamine, and formic acid (the volume ratio was 99,8:0,1:0,1).

\section{Results}

The authors obtained the following fractions: lysophosphatidylcholine, lysophosphatidylethanolamine, sphingomyelin, phosphatidylcholine, phos- phatidylethanolamine, phosphatidylinositol, and phosphatidylserine.

An increase in the level of toxic lysophospholipids (lysophosphatidylcholine and lysophosphatidylethanolamine) and a simultaneous decrease in the levels of phosphatidylcholine in the blood cell membranes indicate the process of membrane destruction and a reduction of functional activity of cells, while the total cell count does not change. The changes in such fractions as phosphatidylethanolamine and phosphatidylinositol reflect the transformation of metabolic cytochemical processes of cells and changes in their reactivity. Routine methods of laboratory diagnostic used for patients with pulmonary tuberculosis do not provide such changes. The changes in the lipid spectrum detected by HPLC are the earliest markers of adaptive and pathologic shifts in the patient's organism. The diagnostic and timely correction of the detected changes contributes to an improvement of the efficacy of treatment for patients with pulmonary tuberculosis.

\section{Conclusion.}

The authors obtained the main fractions of phospholipids, including minor ones. Good separation of peaks and results of the high resolution were obtained.

The identification of the lipid spectrum of the blood and cell membranes allows the specialists to expand their knowledge on the pathogenesis of the tuberculosis process. The obtained data can be used for pathogenetic therapy for pulmonary tuberculosis. Phospholipids exert also immunomodulation properties. They affect the activation of the macrophage-phagocytic system. Phospholipids affect stem cells increasing the formation of hemopoietic foci.

The application of HPLC with a photometric sensor significantly simplifies and accelerates the study of the lipid spectrum and the obtained results become more reliable.

\section{References}

1. Рясенский, Д. С. Влияние противотуберкулезных препаратов первого ряда на уровень токсических фосфолипидов плазмы крови / Д. С. Рясенский, А. В. Асеев, Г. М. Зубарева // Научные результаты биомедицинских исследований. - 2020. - Т. 6. - № 4. - С. 515523. - DOI 10.18413/2658-6533-2020-6-4-0-7.

2. Митянина В.А., В.Н. Купцов, С.В. Савельев, В.И. Швец, А.А. Селищева. Липидный состав эритроцитов детей на разных стадиях заболевания диабетом 1-го типа. // Биомедицинская химия. - 2012. - Т. 58. - №1. - С. 95-103.

3. Синилова Н.Г. Изучение иммуномодулирующих свойств фосфолипидов // Вопросы мед. химии. - 1990. - Т. 36, вып. 3. - С. 34 - 36.

4. Сычёв К.С. Практическое руководство по жидкостной хроматографии.- М.: «Техносфера», 2010.- 272 c.

5. Хабиб О. Туберкулез: Настоящее и будущее // Русский медицинский журнал. - 1999. - №5. - С. 1 - 14. 
6. Gurr, M. I. Lipid metabolism in man [Text] / M. I. Gurr // Proc. Nutc. Soc. - 1988. - Vol. 47, № 3. - P. 277 - 285.

7. Korzhenevskii D.A., Kuptsov V.N.,. Mityanina V.A,. Selishcheva A.A, Saveliev S.V. Identification of the Individual Molecular Species of Ceramides Derived from
Human Erythrocytes using HPLC/MS and HPLC/MS/MS.

// J. Anal. Chem. - 2011. - V. 66. - P. 1270 - 1275.

8. Tang, J. H. Metabolism of phospholipids on erythrocyte membranes [Text] / J. H. Tang, Y. Q. Lu // Sheng. Li. Hsueh. Chin. Chan. - 1990. - Vol. 21, №1. -P. 31 -35.

УДК $616.1 / .9$

https://doi.org/10.52692/1857-0011.2021.3-71.16

\title{
REMOTE RESULTS OF TREATMENT IN PATIENTS WITH PULMONARY TUBERCULOSIS AND PREVIOUS INEFFECTIVE THERAPY
}

\author{
Dmitriy Sergeevich RYASENSKIY, Candidate of Medical Sciences, Associate Professor at the Department of \\ Phthisiology \\ Alexander Vladimirovich ASEEV, Doctor of Medical Sciences, Head of the Department of Phthisiology \\ Akhmed Ibragimovich ELGALI, Assistant at the Department of Phthisiology
}

Tver State Medical University of the Ministry of Health of the Russian Federation, Department of Phthisiology, 170100, Tver, Russia

\section{Summary.}

Until recently, bedaquiline and linezolid were relatively unavailable in antituberculosis dispensaries. Patients that needed these drugs were directed to specialized Federal antituberculosis institutions. The study was aimed to evaluate remote results of the treatment of patients with drug-resistant pulmonary tuberculosis who had previous ineffective therapy at a local antituberculosis dispensary and directed to specialized Federal antituberculosis institutions. A total of 143 patients of both sexes aged 20-60 years old were examined. These patients received therapy at the Tver Regional Clinical Antituberculosis Dispensary in 2010-2014. To increase adherence to the treatment, a complex of measures were taken that included an individual session with a specialist, organization of communication with other patients that received effective therapy for tuberculosis, and watching of an educational video. A complex of measures on an increase in the adherence to the treatment among patients with pulmonary tuberculosis provided positive results in 143 patients. These patients agreed to possible surgical intervention in the Federal Antituberculosis Institution. After the surgical treatment, cavity closure and/or abacillation were registered in 132 patients. Adherence to the consumption of antituberculosis drugs significantly increased in the studied patients.

Keywords: Pulmonary tuberculosis, anti-tuberculosis treatment, anti-tuberculosis drugs.

Резюме. Отдаленные результаты лечения у больных туберкулезом легких при неэффективности предшествующей терапии

До недавнего времени бедаквилин и линезолид были относительно недоступны в условиях противотуберкулезных диспансеров, пациентов, которые нуждались в таком лечении направляли в специализированные Федеральные противотуберкулезные учреждения. Целью исследования явилось изучение отдаленных результатов лечения больных лекарственно резистентным туберкулезом легких при неэффективности предшествующей терапии в противотуберкулёзном диспансере и направлении в специализированное Федеральное противотуберкулезное учреждение. Обследованы 143 человек обоего пола в возрастной группе от 20 до 60 лет, получавшие лечение в Тверском областном клиническом противотуберкулезном диспансере в 2010-2014 гг. В процессе повышения приверженности к лечению использовали индивидуальную беседу, организацию общения с другими больными, получившими эффективное противотуберкулезное лечение, просмотр обучающего видеофильма. При проведении мероприятий по повышению приверженности к лечению среди больных туберкулезом легких положительный результат получен у 143 человек, эти больные согласились на возможное хирургическое вмешательство в Федеральном противотуберкулезном учреждении. Непосредственно после хирургического этапа лечения достигнуто закрытие полостей распада и/или абациллирование у 132 человек. Дисциплинированность больных в приеме противотуберкулезных препаратов значительно повысилась.

Ключевые слова: Туберкулез легких, противотуберкулезное лечение, противотуберкулезные препараты. 